\title{
Youth Perception of Corruption Behavior in the Bureaucracy Kudus District
}

\author{
Dyah Lituhayu ${ }^{1}$, Maesaroh $^{2}$ \\ \{lialituhayu@gmail.com ${ }^{1}$ \} \\ Universitas Diponegoro, Indonesia ${ }^{1,2}$
}

\begin{abstract}
This research aims to describe the perception of youth of corruption behavior the bureaucratic in Kudus District. This research used qualitative method. Corruption is a disease that affects almost all over the world. Corruption is the enemy of the bureaucracy and society. Regent of Kudus was arrested for the second time due to corruption the reelection of former corruptors to became regents can't be separated from the support of society, including youth generation. The research results that show the public has a permissive attitude towards former corruptors to return to serving as regional heads. The public perception that occurs corruption is support of culture society. The youth generation told that society have been accepted bribery is money politics in regional head election. That is 'petty corruption' has accepted as habit. The acceptance of former corruptors because our culture has value of forgiving.
\end{abstract}

Keywords: Perception, Petty Corruption, Bribery

\section{Introduction}

Corruption is a disease that afflicts most government bureaucracies around the world, as well as Indonesia. This is shown by the large number of government officials in the Indonesian bureaucracy have been corrupt behavior. Even recently it occurred in Kudus district. Corruption Eradication (KPK) arrested the Regent of Kudus, M. Tamzil, who was again dealing with a corruption case. For the case that caught him this time, Tamzil is facing the death penalty.

Efforts to minimize $\mathrm{KKN}$ are an important agenda as a priority in government reform (bureaucracy). Departing from the above, it is necessary to find out how the public's understanding, especially youth generation, sees the phenomenon of the high rate of corruption in Indonesia. M. Tamzil was caught through OTT on the alleged case of promotion of officials a position in bureaucracy government. When he was arrested, he was not alone. The KPK also arrested eight other people who were suspected of being involved.

In 2003, Tamzil abused his position in a corruption case of aid funds and education infrastructure for Kudus Regency for the 2004 fiscal year. At that time, Tamzil was a staff member at the Research and Development Agency (Balitbang) Central Java Province. (Liputan6.com. 2019) While the case that ensnared the Kudus regent as a result of the KPK OTT was the alleged bribery case of buying and selling positions and gratuities (Jatengtoday.com. 2020).

The condition of a former corruptor being able to serve again as a regional head is certainly very interesting. And the success of a former corruption convict who can take office 
again cannot be separated from the support of the community itself. The success of a former corruptor who holds office again or is re-elected as regent is certainly a social fact that is quite interesting to study. The winner of a former corruptor being head of regency, it's also depending of societies whose support him.

There are many factors that cause the high rate of corruption, both internal factors in the bureaucratic organization itself and external factors. Therefore, this study will look at external factors of bureaucracy, namely the perception of society, which in this case focuses on youth generation.

The perception of these adolescents is considered necessary to remember them as the youth generation who will become the driving force for national development, must be prepare to build anti-corruption behavior.

Adolescents as youth generation full of idealism need to be explored first, how their attitude towards social facts the bureaucracy which is full of deviant behaviour especially corruption. And as we know in the early history of the breakthrough, it is necessary to have bureaucratic reform driven by students in 1997. So that there is nothing wrong if implementation of reform until now that has been needs to be monitoring, from the point of view of purpose reform relation of corruption; collusion and nepotism (KKN).

Perception is necessary because corruption and corruption perception can be considered as a cultural phenomenon. Based on this understanding that corruption must also be considered as a cultural phenomenon, it is only natural that studies on adolescent perceptions need to be examined. As a cultural phenomenon, society inevitably, especially in this study, adolescents have a role in the growth and development of corrupt behavior in the bureaucratic environment. According sociological scientist death and the development of a culture depend on the community itself.

\section{Methodology}

This type of research is descriptive by using qualitative methods. Data collection used indepth interview and FGD, and secondary data. Informant of the research is member of youth organization Karang Taruna.

\section{Results and Discussion}

Our behavior is not only a function of our personality, values, and preferences, but also of the situation. We interpret our environment, formulate responses, and act accordingly.

Corruption comes from the Latin corrumpere, which means to abuse, deviate, destroy, break. What is being abused? authority or power (misuse of power). Deviating from what? of legal rules and norms or morals. Crush or break what? Breaking or breaking trust. This means that the word corruption has a very negative meaning because it refers to a behavior that is destructive and very detrimental [1].

Perception is important. Perception according to Gilbert Harrell is the process used by individuals to select, organize and interpret information inputs to create a meaningful picture of the world. Perception does not only depend on physical stimuli but also on stimuli related to the surrounding environment and the circumstances of the individual concerned. 
Perception is the experience of objects, events or relationships obtained by inferring information and interpreting messages. Perception is giving meaning to sensory stimuli [2].

Perception does not only depend on physical stimuli but also on stimuli related to the surrounding environment and the condition of the individual concerned.

In understanding perception, things that cannot be ignored are how information is interpreted and given meaning. In giving this meaning, an individual cannot ignore external factors, especially those related to the socio-cultural system. Perception may be defined as the process with which individuals detect and interpret environmental stimuli. What makes human perception so interesting is that we do not solely respond to the stimuli in our environment.

Research on perceptions of corruption has been conducted by Melger, Rossi and Smith [3], the perception of corruption says that corruption and the perception of corruption can be considered as a social phenomenon and is caused by people's understanding of the rules and the constitution regarding deviations.

The research findings the basically, youth understand about corruption, and even show that corrupt behavior cannot be separated from political interests. The field findings in this study show that the younger generation perceives that corrupt behavior is a common thing in people's lives. Because in everyday life we do not can be separated from political life, and in reality, our bureaucracy is full of political interests. So why did former corruption convicts win again in the Pilkada in Kudus is none other than because they are related to the bearing party. Because the bearer party has many seats in the legislature, then the victory obtained by a former convict of corruption.

Efforts to win candidates in regional head elections have become a habit or culture in society to get "money politics" of the people as voters will definitely get an envelope and people think this has become a habit as well as an obligation for regional head candidates to provide it. This finding shows how the habit of receiving money in regional head elections has been considered a culture.

Due to high political costs, it is commonplace that the winning regional head will seek profit through the power and authority he has. This finding is in accordance with the theory put forward by Kiltgaard [4], C = M + D - A that corruption occurs because of the monopoly of power held by someone who has freedom of action or excessive authority without clear accountability.

And the corruption case committed by the Kudus regent is related to the 'price' of a position in the bureaucratic structure. Especially for strategic positions in the government bureaucratic structure, where the arrangement of ASN within the bureaucracy is the full authority of the regional head.

This field finding is also in line with the research results of Bernandez [5], corruption can be seen as the use of power/public officials for individual purposes. He argues corruption as a social phenomenon is a very complex concept. It is a phenomenon that exists in the world. The assumption used to explain this is that human behavior is caused by complex things from the interaction of social, political, economic and cultural structures that involve various factors. It is assumed that human behavior is caused by various factors: social; economy; political and cultural structures. The assumption used is that the corrupt behavior of an individual depends on various political factors, legal, social and cultural elements.

In addition to the findings above, why youth generation also support former corruptors to sit back as officials is due to the cultural value that humans must be able to forgive someone's mistakes. Departing from this cultural value, the Kudus regent chosen is a former corruption convict, no problem, because everyone must have never made mistakes, so it doesn't matter if the former corruptor takes office again, we don't have to look at the past. 


\section{Conclusion}

In accordance with the purpose of the research which want to describe youth perception of corruption behavior, it was found that youth said that cause of corruption behavior is:

a) Political when election of head regent used money politic that is briberies and society has accepted. Society have been advantage.

b) Culture. According youth corruption behavior it forgives former corruption doesn't matter.

\section{References}

[1] Z. Abidin and A. G. P. Siswadi, Psikologi korupsi: memahami aspek-aspek psikologis pelaku korupsi, pola-pola perilaku korupsi, dan pola-pola penanganan korupsi di Indonesia. PT Remaja Rosdakarya, 2015.

[2] J. Rahmat, Psikologi Komunikasi. Bandung: Remaja Rosdakarya, 2007.

[3] N. Melgar, M. Rossi, and T. W. Smith, "The perception of corruption," Int. J. Public Opin. Res., vol. 22, no. 1, pp. 120-131, 2010.

[4] R. Klitgaard, "Membasmi Korupsi," Jakarta Yayasan Obor Indones., 2001.

[5] P. B. Bernaldez, "Determinants of political corruption: A conceptual framework," Int. J. Graft Corrupt. Res., vol. 1, no. 1, 2014. 